\title{
Menyelesaikan Masalah Intoleransi: Analisis Peran dan Bentuk Komunikasi (Studi Kontroversi pondok Pesantren Waria Al-fatah Yogyakarta)
}

\author{
Muhyidin Abdillah', Nila Izzamillati ${ }^{2}$ \\ UIN Sunan Kalijaga Yogyakarta \\ 1abdillahmuhyidin199@gmail.com, 2nilaizza88@gmail.com
}

\begin{abstract}
ABSTRAK
Indonesia adalah negara multikultural yang menjunjung tinggi nilai-nilai toleransi. Namun seiring perkembangan zaman yang semakin canggih nilai toleransi tersebut semakin hilang. Toleransi yang selalu dijunjung tinggi kini berganti dengan sikap intoleransi yang semakin sering terjadi pada era digital yang semakin canggih ini. Intoleransi adalah masalah serius yang harus dihadapi Indonesia. Era digital memudahkan masyarakat untuk menyebar luaskan informasi. Namun, era yang semakin canggih ini jika tidak dimanfaatkan dengan baik maka akan menimbulkan permasalahan. Salah satunya permasalahan intoleransi yang terjadi di Pondok Pesantren Waria Al-Fatah Yogyakarta. Permasalahan tersebut terjadi lantaran ada sebuah informasi dari suatu media yang masih diragukan kebenarannya. Waria yang merupakan kelompok yang rentan yang kehadirannya hanya dipandang sebelah mata baik oleh negara maupun masyarakat. Sehingga, waria yang hanya kelompok minoritas kerap mendapat tindakan diskriminatif dari kelompok ormasormas intoleren. Kelompok ormas intoleren tersebut menuntut untuk menutup pesantren yang menjadi tempat berkumpul waria dalam menuntut ilmu agama. Maka kemudian hal tersebut menarik untuk dikaji. Penelitian ini bertujuan untuk mengetahui peran dan bentuk komunikasi dalam menyelesaikan masalah intoleransi di Pondok Pesantren Waria Al-Fatah Yogyakarta. Penelitian ini menggunakan pendekatan deskriptif kualitatif dengan teknik analisis Miles and Huberman. Sedangkan pengumpulan data melalui observasi, wawancara dan dokumentasi. Hasil penelitian ini adalah Intoleransi yang terjadi di Pondok Pesantren Waria Al-Fatah terjadi lantaran adanya kesalahanpahaman dalam berkomunikasi dan ulah dari ormas-ormas intoleren dalam menyebarkan informasi. Komunikasi memiliki peran penting dalam menyelesaikan masalah tersebut. Bentuk komunikasi antar kelompok dengan tujuan mediasi masalah berhasil dilakukan oleh pihak-pihak terkait. Komunikasi antar kelompok yang terdiri dari pihak pesantren, pemerintah dan masyarakat memberikan solusi bagi masalah intoleransi tersebut.
\end{abstract}

Kata Kunci: Komunikasi, Intolerensi, Pesantren Waria Al-Fatah

\begin{abstract}
Indonesia is a multicultural country that upholds the values of tolerance. But along with the development of increasingly sophisticated times the value of tolerance is increasingly lost. Tolerance that is always held in high esteem is now replaced by an attitude of intolerance that is increasingly common in this increasingly sophisticated digital era. Intolerance is a serious problem that must be faced by Indonesia. The digital age makes it easy for people to spread information. However, this increasingly sophisticated era if not utilized properly will cause problems. One of them is the problem of intolerance that occurs in the waria boarding school Al-Fatah Yogyakarta. This problem occurs because there is information from a media that is still in doubt. Transvestites who are vulnerable groups whose presence is only underestimated by both the state and society. Thus, transgenders who are only a minority group often receive discriminatory actions from intolerant mass organizations. The intolerant mass organization demands to close the pesantren which is a gathering place for transvestites to study religion. So then it is interesting to study. This study aims to determine the role and form of education in solving problems of intolerance in the waria al-Fatah Islamic boarding school in Yogyakarta. This study uses a qualitative descriptive approach with Miles and Huberman analysis techniques. While data collection through observation, interviews and documentation. The results of this study are intolerance that occurs in the Al-Fatah transgender boarding school due to misunderstandings in communication and acts of intolerant mass organizations in spreading information Communication has an
\end{abstract}


important role in resolving these problems. Form of communication between groups with the aim of mediating the problem successfully carried out by the parties concerned. Communication between groups consisting of pesantren, government and the community provides solutions to the problem of intolerance.

Keywords: Communication, Intolerance, Pesantren Waria Al-Fatah

\section{PENDAHULUAN}

Indonesia sedang dihadapkan pada sebuah fenomena besar yakni fenomena perkembangan teknologi yang semakin cepat. Perkembangan teknologi yang semakin cepat mengakibatkan perubahan besar bagi Indonesia. Sehingga hampir seluruh sendi kehidupan masyarakat Indonesia terkena dampak perkembangan teknologi. Layanan internet adalah salah satu bentuk perkembangan teknologi. Menurut APJII (Asosiasi Penyelenggara Jasa Internet Indonesia) pengguna internet di Indonesia tahun 2018 saja sudah mencapai 171,17 juta pengguna. Jumlah tersebut setara dengan $64,8 \%$ penduduk Indonesia yang menggunakan Internet.

Namun dibalik perkembangan teknologi yang begitu cepat Indonesia kini dihadapkan dengan era disrupsi. Disrupsi dalam KBBI diartikan sebagai suatu hal/perkara yang tercabut dari akarnya. Apabila diartikan dalam kehidupan sehari-hari maka istilah disrupsi diartikan sebagai keadaan masyarakat yang menggeserkan aktivitas sehari-hari di dunia nyata ke dunia maya.

Komunikasi adalah suatu hal penting yang bisa digunakan dalam menyelesaikan suatu masalah. Seperti yang kita ketahui bersama bahwa tanpa adanya komunikasi kegiatan manusia tidak akan berjalan dengan baik. Artinya, dengan adanya sebuah komunikasi diharapkan mampu memberikan hasil pertukaran informasi dan saling mengerti di antara pihak-pihak yang terkait. Namun di era disrupsi ini komunikasi banyak berlangsung di dunia maya, sehingga tidak sedikit komunikasi yang berjalan di dunia maya bisa menimbulkan konflik di dunia nyata. Konflik ini dilatar belakangi oleh kesalahpahaman beberapa pihak dalam menyikapi informasi atau karena adanya oknum-oknum yang dengan sengaja menyebarkan informasi yang tidak benar.

Komunikasi bahkan sering menimbulkan kesalahpahaman yang kemudian bisa menimbulkan konflik sosial. Namun di sisi lain komunikasi juga dapat meredakan konflik bahkan mencegah terjadinya konflik sosial. Manusia dalam berkomunikasi sering mengedepankan ambisinya sehingga sering merekayasa akal sehatnya demi nafsunya. Karena adanya ambisi itulah yang kemudian menggerakkan komunikasi lebih bersifat inkonsistensi, sentimental, dan emosional. Sehingga komunikasi yang dihasilkan tidak lagi rasional dan banyak menimbulkan salah paham. Komunikasi yang menimbulkan kesalahpahaman inilah yang menjadi penyebab terjadinya konflik sosial berkembang di berbagai lingkungan.

Di sisi lain komunikasi mampu meredakan konflik dan mencegah terjadinya konflik. Upaya penyelesaian konflik dengan komunikasi bisa melalui proses negosiasi dan mediasi. Menurut Fisher (2001:115) negosiasi adalah merupakan proses terstruktur yang digunakan oleh pihak yang terkonflik untuk melakukan dialog terkait isu di mana masing-masing pihak memiliki pendapat yang berbeda.

Toleransi adalah salah satu contoh permasalahan yang kerap terjadi di era disrupsi ini. Indonesia yang terkenal sebagai negara yang selalu menjunjung tinggi nilai-nilai toleransi kini mulai terjadi pergesaran nilai-nilai toleransi tersebut. Pergeseran nilai tersebut dipengaruhi oleh perkembangan teknologi yang semakin cepat. Indonesia adalah negara yang multikultural dengan beragam suku, ras, bahasa dan agama di dalamnya. Menurut sensus BPS tahun 2010 Indonesia memiliki 1.340 suku. Menurut kemendikbud terdapat 652 bahasa di Indonesia. Jumlah tersebut tidak termasuk dialek dan subdialek. Setidaknya ada 6 agama yang diakui di Indonesia. Dengan keberagaman tersebut sikap toleransi harus dimiliki oleh setiap penduduk Indonesia.

Namun tidak dipungkiri karena perbedaan-perbedaan tersebut tak jarang menimbulkan gesekan-gesekan di masyarakat. Terlebih sejak semakin cepatnya perkembangan teknologi. Intoleransi menjadi satu masalah besar yang harus dihadapi Indonesia dalam era digital ini. Intoleransi sendiri terjadi karena adanya salah paham antara beberapa pihak saja. Salah paham ini kebanyakan terjadi karena banyaknya berita atau informasi digital yang tidak sesuai dengan kenyataan di lapangan. Sehingga hal yang paling dirugikan dalam permasalahan intoleransi adalah kelompok- 
kelompok minoritas di masyarkat. Menurut Imparsial setidaknya terdapat 31 kasus intoleransi sepanjang 2019. Intoleransi yang terjadi rata-rata adalah pelanggaran terhadap kebebasan beragama dan berkeyakinan.

Kelompok waria adalah salah satu kelompok yang terkena dampak masalah intoleransi. Waria (wanita-pria) yang secara umum diartikan sebagai laki-laki yang lebih suka berperan menjadi wanita. Sedangkan secara sosiologis waria diartikan sebagai transgender, yaitu mereka yang menentang kontruksi gender yang berlaku di masyarakat yakni laki-laki atau perempuan. Tetapi transgender disini mempunyai pengertian wanita yang terjebak dalam tubuh laki-laki (Pujileksono, 2005:9). Jika dilihat berdasarkan alat kelaminnya waria adalah laki-laki namun memiliki jiwa perempuan. Sehingga waria lebih cenderung untuk berperilaku sebagai wanita. Hal tersebutlah yang menimbulkan stigma negatif masyarakat terhadap waria karena ketidaksesuaian peran yang yang dijalankannya. Oleh karena itulah waria cenderung tidak diakui di masyarakat.

Padahal seharusnya waria bisa memperoleh kehidupan yang layak sebagaimana kehidupan manusia pada umumnya. Namun karena adanya diskriminasi terhadap waria sehingga waria kini menjadi kelompok yang terpinggirkan dari kelompok-kelompok masyarakat lainnya. Begitu pun dalam hal beragama waria seolah-olah dicap berdosa dan tidak boleh beribadah sebelum mereka kembali ke hakikatnya sebagai laki-laki. Sehingga sering sekali waria mendapatkan tindakan diskriminasi setiap kali hendak beribadah.

Pondok Pesantren Waria Al-Fattah adalah salah satu contoh kelompok waria yang mendapat perlakuan intoleransi. Pondok Pesantren Waria Al-Fattah merupakan bentuk perlawanan terhadap diskriminasi yang waria dapatkan. Pesantren ini didirikan bertujuan supaya waria lebih nyaman dalam beribadah dan belajar agama.

Namun, karena adanya kesalahpahaman tentang informasi yang beredar di media massa pesantren ini pernah dipaksa ditutup oleh sekolompok massa yang mengatas namakan FJI (Front Jihad Islam) pada 19 Februari 2016 (Anang Zakaria, 2016). Alasannya adalah adanya isu yang beredar di media massa bahwa pesantren tersebut hendak membuat fikih waria. Selain itu ada alasan lainnya yaitu ketidaknyamanan para warga karena rumah yang dipakai untuk pesantren adalah milik Shinta yang posisinya di tengah-tengah pemukiman warga dan tak memiliki izin untuk dijadikan lembaga. Penutupan ini terjadi atas dasar kesepakatan banyak pihak, ada pertemuan pengelola pesantren, perwakilan warga, dan pimpinan Front Jihad Islam (FJI). Tak hanya itu ternyata, ada juga perwakilan dari pejabat Kecamatan, Kapolsek, Danramil, KUA, serta beberapa tokoh masyarakat. Alasan lain di samping warga yang keberatan adalah pendapat bahwa pesantren itu juga dianggap bertentangan dengan nilai-nilai Islami.

\section{METODE PENELITIAN}

Penelitian ini merupakan jenis penelitian deskriptif kualitatif. Menurut Bogdan dan Taylor, "metode kualitatif sebagai proses penelitian yang menghasilkan data deskriptif berupa kata-kata tertulis atau lisan dari orang-orang dan perilaku yang dapat diamati". (Bagong Suyanto, 2006 : 166 ).

Konsep pengertian penelitian kualitatif menunjukkan dan menekankan pada proses. Penelitian kualitatif menekankan sifat realitas yang dibangun secara sosial, hubungan yang intim antara peneliti dengan yang dipelajari dan kendala situasional yang membentuk penyelidikan (Agus Salim, 2001:11 ) .

Suatu penelitian lazimnya menggunakan macam-macam data antara lain yaitu, manusia dan dokumen. Adapun penelitian ini menggunakan jenis data berupa hasil wawancara dan observasi serta literatur-literatur yang mendukung.

Model analisa data yang digunakan dalam penelitian ini yaitu model analisis interaktif. Analisis interaktif akan lebih bermanfaat bagi penelitian yang bersifat deskriptif ataupun eksplanatif. Dalam metode analisis interaktif terdapat komponen analisis berupa:

a. Reduksi data, adalah proses seleksi, pemfokusan, penyederhanaan, dan abstraksi data dari lapangan yang berlangsung terus hingga laporan akhir penelitian. Reduksi data dilakukan setelah data terkumpul secara lengkap. 
b. Penyajian data, berupa rakitan informasi, deskripsi dalam bentuk narasi yang memungkinkan simpulan penelitian dapat dilakukan.

c. Penarikan kesimpulan dan verifikasi, dapat berupa kegiatan yang dilakukan dengan lebih mengembangkan ketelitian dengan cara diskusi. Simpulan juga harus diverifikasi agar mantap dan bisa dipertanggungjawabkan. (Sutopo, 2002: 91-93).

\section{HASIL DAN PEMBAHASAN \\ Pondok Pesantren Waria}

Kata "pesantren" berasal dari kata santri, dengan awalan pe- dan akhiran -an, yang berarti tempat tinggal santri (Dhofier Zamakhsyari: 1992, 18). Pesantren merupakan bagian dari pendidikan nasional yang telah ada sebelum kemerdekaan dan bahkan disinyalir sebagai lembaga pendidikan yang memiliki kekhasan, keaslian (indegeneous) Indonesia. Ziemeh menegaskan bahwa asal etimologi dari pesantren adalah pe-santri-an yang berarti "tempat santri".

Selanjutnya pondok pesantren diartikan oleh Haidar Putra Daulay (2001:8-9) sebagai suatu lembaga pendidikan Islam Indonesia yang bertujuan untuk mendalami ilmu agama islam dan mengamalkannya sebagai pedoman hidup keseharian, atau disebut tafaqquh fi ad-din dengan menekankan pentingnya moral dalam hidup bermasyarakat, yang berorientasi memberikan pendidikan dan pengajaran keagamaan.

Sementara Clifford Geertz (1983:268) berpendapat bahwa kata santri mempunyai arti luas dan sempit. Dalam arti sempit santri adalah seorang murid satu sekolah agama yang disebut pondok atau pesantren. Oleh sebab itu, perkataan pesantren diambil dari perkataan santri yang berarti tempat untuk para santri. Dalam arti luas, santri adalah bagian dari penduduk Jawa yang memeluk Islam secara benar-benar, bersembahyang, pergi ke masjid dan berbagai aktivitas lainnya.

Waria merupakan akronim dari wanita-pria, yaitu orang yang secara fisik adalah laki-laki normal, namun secara psikis ia merasa dirinya adalah perempuan. Akibatnya, perilaku yang mereka tampilkan dalam kehidupan sehari-hari cenderung mengarah kepada perempuan, baik dari cara berjalan, berbicara maupun berdandan (make up).

Dengan demikian bahwa kata pesantren waria memiliki makna substantif sebagai tempat bagi santri (dalam hal ini adalah waria) untuk memahami dan mendalami ilmu-ilmu agama, serta mengamalkan ilmu-ilmu tersebut dalam kehidupan sehari-hari, sehingga ilmu-ilmu agama tersebut mampu menjadi way of life atau dengan kata lain, disamping sebagai sebuah lembaga pendidikan, pesantren juga memiliki peran sebagai sebuah lembaga pemberdayaan masyarakat.

\section{Profil Pesantren Waria Al-Fattah}

Pesantren Waria Al-Fatah menjadi hal menarik untuk melihat keagamaan santri yang seluruhnya merupakan waria. Selama ini waria yang sering terlihat di jalanan dalam kehidupannya lebih mengarah pada hal yang negatif dan mengenai cara bertahan hidup antar komunitas sesamanya. Namun hal tersebut berbeda dengan kehidupan para waria yang menjadi santri di Pesantren Al-Fattah ini.

Pondok pesantren Al-Fattah adalah pondok pesantren yang berada di Celenan, Kotagede Yogjakarta yang di khususkan untuk waria. Pesantren ini didirikan pada bulan September 2008. Pesantren ini didirikan oleh seorang waria yang dikenal dengan panggilan ibu Maryani. Kemudian kepemimpinan di pesantren ini dilanjutkan oleh Shinta Ratri, pasca Maryani meninggal dunia pada tahun 2014.

Pada mulanya tahun 2006 terjadi gempa di yogjakarta yang berkekuatan 5,9 skala richter dalam waktu 57 detik merenggut nyawa beberapa dari waria. Peristiwa tersebut mampu menyentuh nurani mereka untuk mengadakan doa bersama yang di pimpin oleh KH. Hamroeli setiap bulannya. Maka kemudian muncul ide untuk mendirikan Pondok Pesantren yang bertujuan untuk memfasilitasi waria supaya bisa belajar agama. Pada awalnya Pondok Pesantren Al-Fattah bertempat di rumah kontrakan Ibu Maryani yang bertempatan di Notoyudan. Menurutnya waria juga makhluk Tuhan yang berhak mendapatkan perilaku yang sama dengan lainnya. 
Di sini para waria bisa beribadah dengan nyaman tanpa mendapatkan diskriminasi. Artinya, waria dipersilahkan untuk mengekspresikan dirinya ketika beribadah. Jika ada yang lebih nyaman memakai sarung layaknya pria, maupun lebih nyaman memakai mukena layaknya wanita ketika hendak melakukan ibadah mereka dipersilahkan tanpa ada yang melarang. Faktor terpentingnya adalah mereka bisa berkomunikasi dengan Tuhannya. Sebelum ada Pesantren ini para waria kesusahan mencari tempat untuk beribadah selain di rumah atau kamarnya sendiri karena tidak semua orang bisa menerima mereka.

Pondok Pesantren Al-Fattah juga menggunakan kurikulum yang disesuaikan oleh para santri yang dominan hanya lulusan SMP saja. Pembimbing Pondok Pesantren Al-fattah memilik 4 ustadz dan 1 ustadzah yang merupakan lulusan S2 dari UIN Sunan Kalijaga dan Universitas Gajah Mada. Pesantren ini memiliki 42 santri dari berbagai daerah. Para santri waria ini ingin sisa hidupnya menjadi lebih baik dari sebelumnya. Pesantren waria ini dapat berdiri dengan kokoh di tengah fenomena sosial yang cenderung memojokkan para waria. Kegiatan yang ada di pesantren sendiri diantaranya arisan, koperasi, hafalan surat pendek, kelas bacaan sholat, kelas tajwid, tadarus Alqur'an dan bagi yang belum bisa membaca Al-Qur'an maka di ganti dengan belajar Iqro', serta belajar kitab kuning.

\section{Kontroversi Pondok Pesantren Waria Al-Fattah}

Waria dalam konteks psikologis termasuk sebagai penderita transeksualisme, yaitu seseorang yang secara fisik memiliki jenis kelamin yang jelas dan sempurna, namun secara psikis cenderung untuk menampilkan diri dalam bentuk lawan jenisnya. Secara individual munculnya perilaku waria tidak bisa lepas dari suatu proses atau dorongan yang kuat, bahwa fisik seorang waria tidak sesuai dengan kondisi psikisnya. Menurut Shinta menjadi waria bukanlah suatu pilihan melainkan waria adalah takdir yang sudah dipilih Tuhan untuknya. Sehingga walau secara fisik waria merupakan pria, namun dalam psikisnya adalah seorang wanita.

Waria dalam konteks sosiologis merupakan makhluk hidup yang sama dengan lainnya. Mereka memilik hak dan kewajiban sebagaimana yang berlaku di masyarakat pada umumnya. Sehingga waria menuntut untuk mendaptkan hak yang sama dengan tatanan masyarakat lainnya. Di sisi lain sebagai makhluk sosial yang dipandang abnormal karena tidak sesuai dengan kontruksi sosial yang berlaku, waria digolongkan sebagai kelompok minoritas bahkan termarjinalkan. Sehingga tidak mengherankan jika waria kerap mendapatkan tindakan diskriminasi dari kelompok masyarakat lainnya.

Dalam kehidupam sosial waria cenderung kurang mendapatkan haknya secara penuh. Hal ini diakibatkan karena perbedaan persepsi masyarakat mengenai waria. Terlebih khusus persepsi masyarakat mengenai Pondok Pesantren Waria Al-Fattah. Ada yang beranggapan bahwa adanya pesantren ini sangat baik dan berguna bagi waria. Karena tentu dengan pendirian pondok pesantren ini dilatarbelakangi dengan maksdu dan tujuan yang baik, yaitu untuk memfasilitasi waria untuk belajar agama, beribadah, bersedekah, ngaji bersama dan berdzikir bersama. Namun ada pula yang beranggapan negatif, anggapan negatif ini dilatarbelakangi karena perilaku waria yang kerap menyimpang dari ketentuan umum yang ada di masyarakat karena ketidak jelasan perilaku waria; tidak berperilaku sebagai pria dan tidak sepenuhnya wanita. Selain itu sudah ada stigma negatif yang menempa kelompok waria. Waria cenderung dikaitkan dengan dunia pelacuran sehingga adanya pesantren ini dianggap sebagai tempat mangkal atau lokalisasi.

Dalam kehidupan beragama waria sering mendapat perlakuan diskriminasi dari masyarakat. Seperti halnya ketika hendak melaksanakan sholat berjamaah, waria cenderung dijauhi dari barisan sholat bahkan dilarang untuk melakukan sholat di mushola/masjid tersebut.

"Kami sering tuh mendapatkan perlakuan yang tidak mengenakan dari masyarakat. Misalnya, ketika hendak sholat jamaah kami dijauhi dari shaf shalat. Mau ikut pengajian malah diusir. Jadi kami ngerasa nggak bebas dalam beribadah"(Shinta).

Kelompok waria sering dikaitkan dengan kelompok sub-altern dalam kehidupan sosial. Istilah subaltern berasal dari pemikir Italia, Antonio Gramsci. Menurutnya, istilah ini merujuk pada kelompok sosial subordinat, yakni kelompok-kelompok dalam masyarakat yang menjadi subjek 
hegemoni kelas-kelas yang berkuasa. Petani, buruh, dan kelompok-kelompok lain yang tidak memiliki akses kepada kekuasaan hegemonik bisa disebut sebagai kelas sub-altern. Dengan kata lain hubungan sub-altern adalah hubungan menindas dan ditindas (Reed: 2012).

Sehingga dengan perbedaan persepsi dan posisi waria yang merupakan kelompok sub-altern menimbulkan konflik tersendiri mengenai Pondok Pesantren Waria Al-Fattah. Konflik merupakan sesuatu yang tidak dapat dihindari oleh manusia sebagai makhluk sosial dalam kehidupan bermasyarakat. Manusia sebagai makhluk individu dalam menjalin hubungan sosial dengan manusia lainnya. Selama manusia memiliki kepentingan yang berbeda maka konflik akan selalu menyertainya dimana pun mereka berada. Perbedaan pendapat serta perbedaan kepentingan adalah satu faktor yang menimbulkan konflik social. Kelompok sub-altern dalam kehidupan bermasyarakat masuk dalam golongan kelompok minoritas, sehingga kelompok minoritas ini adalah korban dalam terjadinya sebuah konflik. Selain sebagai korban kelompok minoritas juga kerap menjadi penyebab terjadinya sebuah gesekan dalam tatanan sosial.

Seperti peristiwa pada tahun 2016 silam yang menimpa Pondok Pesantren Waria Al-Fattah. Waria kerap mendapatkan tindakan diskriminasi dari ormas-ormas intoleren. Ormas tersebut menuntut agar pesantren tersebut ditutup. Dengan bantuan teknologi dan kecepatan penyebarluasan informasi, kelompok tersebut menyebarkan pesan berantai yang berisi untuk menggalang massa solidaritas untuk menutup Pesantren Al-Fattah. Dengan alasan bahwa pesantren ini tidak sesuai dengan tuntutan syariat Islam. Aksi massa tersebut seolah diamini oleh pemerintah kecamatan Jagalan, Banguntapan yang mengklaim bahwa menemukan botol minuman keras di dalam pesantren. Ormas tersebut datang memenuhi daerah sekitar pondok sembari meneriakkan "Allahuakbar." Lantas kelompok ormas ini melanjutkan perkara penutupan ini ke pengadilan. Dalam pengadilan tersebut ormas menginginkan agar pihak pondok pesantren tidak membawa pengacara atau bantuan hukum dari lembaga mana pun. Mereka ingin agar pesantren segera ditutup karena dianggap tidak sesuai dengan syariat Islam. Sehingga pesantren ini ditutup pada bulan Februari tahun 2016.

Namun di sisi lain kelompok waria juga menginginkan kehidupan beragama sebagaimana pada umumnya. Sebelumnya mereka sedikit terbantu dengan adanya pesantren ini. Namun, setelah penutupan penutupan mereka merasa kecewa dengan kejadian itu.

Hingga kemudian ada bantuan dari LBH Yogyakarta yang memperjuangkan hak pesantren ini. Selain itu ada beberapa kelompok masyarakat yang merasa kecewa dengan penutupan pesantren tersebut. Ada kelompok masyarakat yang mengecam tindakan ormas tersebut karena hal tersebut melukai perasaan waria dan membatasi pergerakan kaum waria dalam beribadah. Sehingga hal itulah yang kemudian menjadi latar belakang terjadinya kontroversi penutupan Pesantren Waria Al-Fattah. Kontroversi ini terjadi lantaran adanya ketidakjelasan dan perbedaan persepsi dalam menyikapi dan menanggapi tentang Pesantren Waria Al-Fattah.

\section{Peran dan Bentuk Komunikasi dalam Menyelesaikan Kontroversi Intoleransi Pesantren Waria Al-Fattah}

Komunikasi memiliki peran penting dalam penyelesaian masalah yang terjadi dalam kehidupan bermasyarakat. Menurut Shannon \& Weaver, komunikasi adalah bentuk interaksi manusia yang saling mempengaruhi satu sama lainnya, sengaja maupun tidak disengaja. Peran komunikasi di dalam suatu organisasi sangatlah penting, karena adannya interaksi antar manusia dan saling ketergantungan. Begitupun dalam menyelesaikan sebuah konflik, komunikasi memeliki peran penting di dalamnya. Komunikasi bisa menjadi sebab terjadinya konflik dan juga komunikasi bisa menjadi cara untuk menyelesaikan konflik.

Seperti halnya dalam penyelesaian masalah di Pondok Pesantren Waria Al-Fattah. Komunikasi memiliki peran penting di dalamnya. Dengan adanya komunikasi dengan beberapa pihak yang terkait masalah ini bisa menemui jalan keluarnya. Seperti komunikasi antara pihak pesantren dengan pihak pemerintahan. Pihak pesantren meminta pemerintah untuk memberikan perlindungan dan dukungan moral kepada pesantren waria supaya mereka bisa mencari jalan keluar dari konflik ini. Sehingga melalui komunikasi tersebut Pesantren Waria al-Fattah yang sempat vakum karena penutupan kini bisa berjalan semestinya melalui pendekatan komunikasi. 
Dalam menyelesaikan konflik ada beberapa bentuk komunikasi yang bisa digunakan. Seperti komunikasi interpersonal, komunikasi antarkelompok, komunikasi antarbudaya dan komunikasi massa.

Bentuk-bentuk komunikasi seperti itulah yang digunakan Shinta selaku pimpinan pesantren dalam menghadapi masalah yang menimpa pesantren. Komunikasi interpersonal digunakan ketika sedang berdialog antara Shinta dan santri-santri waria. Saling menguatkan supaya mereka tetap semangat dalam memperjuangkan hak-hak mereka dan semangat dalam beribadah.

Komunikasi antarkelompok menjadi bentuk komunikasi yang paling mendominasi dalam penyelesaian masalah konflik ini. Ada 2 cara yang digunakan negosiasi dan mediasi. Negosiasi adalah proses tawar menawar untuk mencari kesepatakan antara kedua belah pihak. Sedangkan mediasi adalah adalah upaya dalam menyelesaikan konflik antara kedua belah pihak yang bersengketa dengan mengahdirkan pihak ketiga sebagai penengahnya. Pihak pesantren melakukan langkah konkrit dalam negosiasi ini. Sebelumnya tentu ada mediasi yang dilukakan yakni dengan mencari tembusantembusan yang mampu menguatkan mereka. Mereka bertemu dengan Gusti Kanjeng Ratu Hemas untuk meminta dukungan. Kemudian pertemuan mereka disambut baik oleh Ratu Hemas yakni memberikan izin dan mendukung segala kegiatan yang berlangsung di Pondok Pesantren Waria AlFattah. Namun belum ada izin tertulis atau keputusan ketetapan yang diberikan sehingga mereka masih harus mencari dukungan lagi.

Selanjutnya ada komunikasi antara pihak Waria dengan LBH Yogyakarta. Pesantren AlFattah mendapat pendampingan hukum dari LBH Yogyakarta hingga mereka kini menjalin kerjasama. Dari bantuan LBH mereka kemudian melakukan negosiasi ke Komnas HAM dan Komnas Perlindungan Perempuan. Dan kini waria pun mendapat perlindungan dari komnas HAM. Selain ke lembaga pemerintahan, Pesantren Waria Al-Fattah pun mengajukan surat ke Polda DIY supaya mereka diberikan jaminan keamanan oleh jajaran kepolisian. Karena mereka menuntut untuk diberikan rasa aman oleh pihak kepolisian sehingga mereka melakukan kegiatan dengan rasa aman dan tenang.

Untuk mendukung kegiatan mereka juga mencari dukungan dari para tokoh bangsa, agama dan masyarakat. Terlebih sejak MUI memberikan fatwa bahwa segala perilaku waria yang menyimpang adalah haram dan harus dikembalikan ke kodratnya. Sehingga mereka pun mencari dukungan terhadap ormas-ormas yang mengedepankan prinsip humanisme di dalamnya. Alhasil mereka mendapatkan dukungan dari PWNU DIY. Mereka dibantu baik secara individual dengan memberikan tenaga pengajar maupun dibantu secara kelembagaan dengan diberikan dana yang bisa digunakan untuk operasional pesantren. Dari sosok tokoh bangsa mereka meminta dukungan dengan menemui Ibu Shinta Nuriyyah Wahid selaku istri dari presiden Indonesia ke-4 Indonesia.

Sedangkan dalam bentuk komunikasi massa banyak tulisan baik dalam artikel, jurnal dan penelitian lainnya yang mengangkat tentang pondok pesantren ini sehingga stigma yang berlaku di masyarakat sedikit demi sedikit berubah mengenai pandangan terhadap waria. Komunikasi terhadap lingkungan sekitar juga sangat diperlukan untuk mengubah stigma masyarakat, mereka harus menunjukan bahwa kegiatan yang mereka jalani tidak melanggar aturan dan tidak merugikan masyarakat.

\section{SIMPULAN}

Simpulan

Perkembangan Teknologi memiliki peran yang begitu besar terhadap perubahan sosial di masyarakat. Era disrupsi atau perpindahan perilaku dari dunia nyata beralih ke dunia digital mengakibatkan segala bentuk komunikasi berlangsung di media maya. Sehingga konflik-konflik akan bermunculan karena kesalahpahaman informasi di dunia maya. Intoleransi adalah satu konflik nyata akibat perkembangan dana kesalahpahamn komunikasi melalui dunia digital.

Komunikasi menjadi sebab terjadinya konflik-konflik sosial dan menjadi solusi bagi konflikkonflik tersebut. Waria adalah salah satu contoh kelompok minoritas yang kerap menerima perlakuan diskriminasi dari pihak-pihak intoleren. Sehingga perlu adanya komunikasi dalam menyelesaikan masalah diskriminasi terhadap waria. 
Contohnya adalah kontoversi penutupan pondok pesantren waria yang ditutup karena kesalahpahaman informasi dan ulah dari ormas-ormas intoleren. Dalam kontoversi ini komunikasi berperan penting dalam menyelesaikan masalah. Komunikasi dengan bentuk interpersonal, antarkelompok dan massa digunakan dalam menyelesaikan masalah ini.

Saran

Dalam penelitian yang peneliti lakukan di Pondok Pesantren Waria Al-Fattah peneliti memberikan saran kepada pihak pesantren dan pihak-pihak yang terkait untuk memperbaiki pola komunikasi untuk meminimalisir terjadinya kesalahpahaman dalam berkomunikasi.

Dalam penelitian ini masih banyak kekurangan dari peneliti sehingga perlu adanya penelitian lebih lanjut untuk mengetahui permasalahan dan jalan keluar terhadap kasus-kasus diskriminasi yang lebih mengarah kepada tindakan intoleransi.

\section{DAFTAR PUSTAKA}

Agus Salim. 2001. Teori dan Paradigma Penelitian Sosial. Yogyakarta: Tiarawacana

Bagong, Suyanto dan Sutinah. 2006. Metode Penelitian Sosial Berbagai Alternatif Pendekatan. Jakarta: Prenada Media Group

Cangara, Hafied. 1998. Pengantar Ilmu Komunikasi, Jakarta: Raja Grafindo Persada

Daulay, Haidar Putra. 2001. Historisitas dan Eksistensi Pesantren, Sekolah dan Madrasah. Yogyakarta: Tiara Wacana.

Dhofier, Zamakhsyari. 1992. Tradisi Pesantren. Jakarta: LP3ES.

Effendy, Onong Uchjana. 1993. Ilmu, Teori dan Filsafat Komunikasi. Bandung : PT Citra Aditya Bakti

Fisher S., Jawed L., Steve W., Dekha I. A., Richard S. dan Sue W. 2001. Mengelola Konflik, Keterampilan dan Strategi untuk Bertindak. The British Council Indonesia: Jakarta.

Franedya, Roy. (2019) Survei: Pengguna Internet di RI Tembus 171,17 Juta Jiwa, Retrieved $102020 . \quad$ From, 1200 www.cncbindonesia.com

(https://www.cnbcindonesia.com/tech/20190516191935-37-73041/survei-penggunainternet-di-ri-tembus-17117-juta-jiwa)

Geertz, Clifford. 1983. Abangan, Santri, Priyayi dalam Masyarakat Jawa. Jakarta: Dunia Pustaka Jaya.

H.B. Sutopo. 2002. Pengantar Penelitian Kualitatif. Surakarta : Universitas Sebelas Maret Press.

https://www.cnnindonesia.com/nasional/20191117163821-32-449096/imparsial-temukan-31kasus-intoleransi-selama-setahun (diakses pada tanggal 6 Januari 2020 pkl 6:04 Wib)

Mulyana, Deddy,. 2010. Ilmu Komunikasi Suatu Pengantar. Bandung : Rosdakarya

Mulyana, Deddy. 2005. Ilmu Komunikasi. Bandung: PT. Remaja Rosdakarya.

Pujileksono, Sugeng. 2005. Waria dan Tekanan Sosial. Malang: UMM Press

Reed, J. P., 2012. Theorist of subaltern Subjectivity: Antnio Gramsch, Popular Beliefs, Political Passion, and Reciprocal Learning. Sage.

Sendjaja, S. Djuarsa. 1994. Teori Komunikasi. Jakarta: Universitas Terbuka

Winarso, Heru Puji. 2005. Sosiologi Komunikasi Massa. Prestasi Pustaka Publisher.Jakarta

Zakaria, Anang. (2016). Penutupan Pesantren Waria Dinilai Melanggar Hak

Beragama, Retrieved 4 1, 2020. From (https://nasional.tempo.co/read/751799/penutupan-pesantren-waria-dinilai-melanggar-hakberagama/full\&view $=$ ok 
JURNAL ILMIAH KOMUNIKASI MAKNA

Vol.9,No.1, Februari 2021, pp.21-28

E.ISSN:2334-4606, P-ISSN:2087-2461

http://jurnal.unissula.ac.id/index.php/makna

DOI:http://dx.doi.org/10.30659/jikm.9.1.21-28 